Historic, archived document

Do not assume content reflects current scientific knowledge, policies, or practices. 


\section{FEB 211963}

CURRENT SERIAL RLWUKIDS

Some Effects of Packaging and Merchandising

on the Quality of
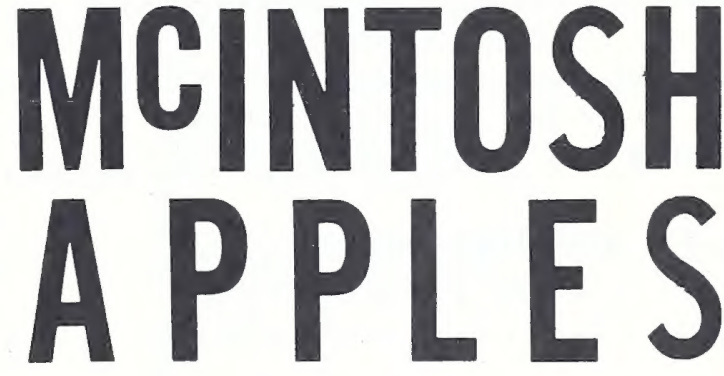

in New York City

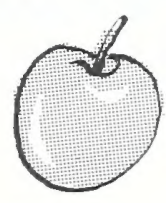

U.S. DEPARTMENT OF AGRICULTURE

Agricultural Marketing Service

Market Quality Research Division 


\section{ACKNOWLEDGMENTS}

The authors are grateful for the cooperation and assistance of the following which made this study possible.

S. \& A. Chaissan and Sons, Highland, N. Y.

Rhapsody Orchards Inc., Marlboro, N. Y.

Twin Oak Farms, Rock Tavern, N. Y.

CONTENTS

Page



Background $\ldots \ldots \ldots \ldots \ldots \ldots \ldots \ldots \ldots \ldots \ldots \ldots \ldots \ldots \ldots \ldots \ldots$

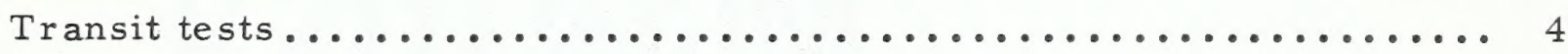

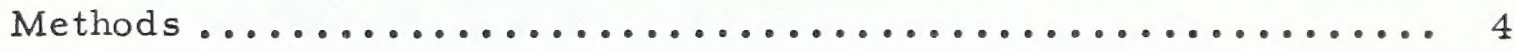

Results and discussion $\ldots \ldots \ldots \ldots \ldots \ldots \ldots \ldots \ldots \ldots \ldots$



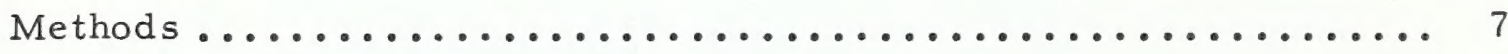

Results and discussion $\ldots \ldots \ldots \ldots \ldots \ldots \ldots \ldots \ldots \ldots \ldots \ldots$



Washington, D. C.

February 1963 


\title{
SOME EFFECTS OF PACKAGING AND MERCHANDISING ON THE QUALITY OF McINTOSH APPLES IN NEW YORK CITY
}

\author{
By Michael J. Ceponis and Jacob Kaufman \\ Horticultural Crops Branch, Market Quality Research Division, \\ Agricultural Marketing Service
}

\section{SUMMARY}

In a comparison of four different packages, cell cartons gave the most protection to McIntosh apples from rough treatment in transit to New. York City from packinghouses 80 to 100 miles away.

Apples prepackaged in trays with heat-shrinkable film, overwrapped and packed in cartons, were next best protected. The weakness of the tray-separating partition was the major failing of this otherwise very satisfactory pack.

The rough transit treatment caused considerable bruising and puncture damage on fruit prepackaged in polyethylene bags. The worst damage occurred on fruit in jumblefilled cartons.

The condition of the fruit in polyethylene bags, in shrink-film overwrapped trays, and from cell packs was compared in New York City supermarkets during 1 - to 2-day retail test periods. In the stores, the quality of McIntosh apples was maintained best in prepackaged trays overwrapped with shrink-film. Apples in the trays had fewer bruises and punctures and, when held 4 days at $70^{\circ} \mathrm{F}$. beyond the retail period, less than 1 percent decayed.

The merchandising of the fruit from cell cartons in bulk, the usual commercial practice, resulted in the bruising and puncturing of many fruit during the retail test period.

Prepackaged poly-bagged fruit sustained the most mechanical injury from the handling encountered in retail stores.

The holding of poly-bagged and bulk-displayed fruit 4 days at $70^{\circ} \mathrm{F}$. past the retail period brought on the development of many decays at the sites of punctures.

\section{BACKGROUND}

Despite recent improvements in the handling of apples in the orchard ( $\underline{8})$, in the packinghouse $(\underline{1}, \underline{3}, \underline{6})$, and during shipment to market $(\underline{5}, \underline{9})$, mechanical injury continues to be the major problem in the merchandising of McIntosh apples. ${ }^{1}$ Surveys in several States $(2,5,7)$, disclosed that the inferior condition of McIntosh apples in retail stores is due chiefly to punctures and bruises. It was found that much of this damage occurs after the apples leave the packinghouse. Good condition in apples when packaged can virtually disappear overnight, sometimes before the fruit reaches the retail shelves. In addition, mechanically damaged fruit is particularly susceptible to decay.

\footnotetext{
${ }^{1}$ Underscored figures in parentheses refer to Literature Cited, p. 9.
} 
The recent innovation of overwrapping fruit in trays with a heat-shrinkable film (4) warranted a comparison of this method of packaging with others in maintaining quality in McIntosh apples. Four different packs, including two with prepackaged units, were tested for apples trucked to New York City from nearby packinghouses. The effect of handling on the condition of the fruit in three of these packages was also studied in retail stores. These tests were part of a broad research program by the Agricultural Marketing Service to reduce losses in quantity and quality of farm products in marketing channels.

\section{TRANSIT TESTS}

\section{Methods}

The apples were packaged at Hudson Valley packinghouses at three intervals, about a month apart, during the fall and early winter of 1961, and trucked 80 to 100 miles to New York City for evaluation of condition. The packages tested were fiberboard cartons with the following contents: (1) Twelve 3-1b. polyethylene bags of apples, vertically positioned in two layers (fig. 1); (2) 120 apples in individual cells formed by fiberboard partitions (fig. 2); (3) twelve 8-apple trays, each overwrapped with a heat-shrinkable film (fig. 3); and (4) jumble-packed fruit. Manufacturers' certifications indicated a bursting test resistance of 200 pounds per square inch for the cartons of packs 1,2 , and 3 , and a 275-pound resistance for the carton that was jumble-filled.

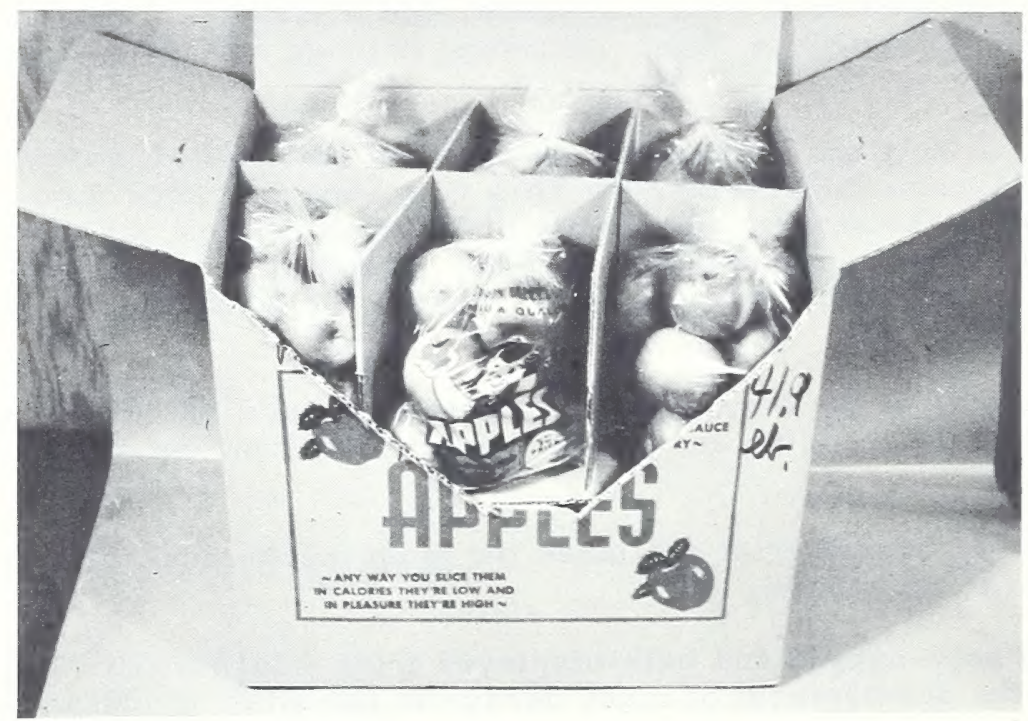

$\mathrm{BN}-17680$

Figure 1. - Carton with twelve 3-1b. polyethylene bags of apples. Part of one side of carton was removed to reveal the vertical positions of the bags,

Apples that were free of mechanical injury or those only slightly affected were used, with the bruises and punctures of the latter scored. The apples approximated $23 / 4$ inches in size and were randomized throughout the different packages, which were made updin pairs for each trip.

Each carton was dropped 6 inches at the start of a trip, 12 inches at a stop-point en route, and 18 inches at the destination to simulate rough handling at the shipping point, at a receiving warehouse, and in the retail store delivery, respectively. In transit, the paired packages occupied similar positions in the truck. 




BN-17681

Figure 2. --The cell carton of 120 apples with the upper layer exposed. There are 4 layers of 30 apples each in the box.



$\mathrm{BN}-17682$

Figure 3. --The 16-tray-capacity master carton. Part of one side of carton was removed to reveal the 4 layers separated by corrugated pads and the 4 shrink-film overwrapped trays separated by the tray partitions in each layer. The 12-tray carton used in transit tests had 3 layers of 4 trays each. 


\section{Results and Discussion}

Inspection of the fruit at destination showed that, in all three runs, the cell packs provided the best protection against mechanical injury (table 1). After discounting those bruises noted at the packinghouse, there remained an average of almost 30 bruises over $1 / 2$ inch in diameter for every 100 apples shipped in the cell cartons. The amount of mechanical damage that occurred was similar in each test despite the softening of the fruit as the storage season lengthened. Stem puncturing was precluded by the cell partitions which compartmented each apple.

The pack with the overwrapped trays was tested in two runs (tests 2, 3) and fared second best (table 1). Because 16-tray-capacity master containers were unavailable during the period of transit testing, a 12 -tray pack was utilized. Despite the comparative advantage of this lighter pack ( 96 apples), a considerable amount of bruising occurred the first time this package was tested. Much of the bruising resulted from the failure of the corrugated tray separator, or partition, to support the overhead layer in the bottom of the carton. These vertical partitions buckled under the stress induced by the dropping of the cartons, and as a consequence, the overhead layer came into contact with the apples at the bottom. In the second run, a partition made from the firmer fiberboard material of a layer pad was substituted and a notable reduction in bruising resulted. No new punctures were produced in the overwrapped fruit.

TABLE 1.-Net increases of punctures and bruises in McIntosh apples after being subjected to rough handling during transit to New York City

\begin{tabular}{|c|c|c|c|c|c|c|c|}
\hline \multirow{2}{*}{$\begin{array}{l}\text { Type of } \\
\text { package }\end{array}$} & \multirow[t]{2}{*}{ Test $^{2}$} & \multirow{2}{*}{$\begin{array}{l}\text { Average } \\
\text { carton } \\
\text { weight }\end{array}$} & \multirow{2}{*}{$\begin{array}{l}\text { Punctures } \\
\text { per } \\
100 \text { fruit }\end{array}$} & \multicolumn{4}{|c|}{$\begin{array}{l}\text { Size and number of bruises } \\
\text { per } 100 \text { fruit }\end{array}$} \\
\hline & & & & $1 / 2^{\prime \prime}-3 / 4^{\prime \prime}$ & $3 / 4 "-1 "$ & Over I" & Total \\
\hline & & $\underline{\mathrm{Lb}}$. & & No. & №. & No. & No. \\
\hline Carton of & 1 & 41.9 & 25 & 37 & 9 & $I$ & 47 \\
\hline $123-1 b$ & 2 & 41.9 & 25 & 58 & 16 & 4 & 78 \\
\hline poly bags. & 3 & 42.0 & 22 & 62 & 34 & 11 & 107 \\
\hline $\begin{array}{l}\text { Carton, } \\
\text { cel1 (120). }\end{array}$ & $\begin{array}{l}1 \\
2 \\
3\end{array}$ & $\begin{array}{l}39.8 \\
38.6 \\
38.9\end{array}$ & $\begin{array}{l}0 \\
0 \\
0\end{array}$ & $\begin{array}{l}18 \\
20 \\
15\end{array}$ & $\begin{array}{l}9 \\
7 \\
9\end{array}$ & $\begin{array}{l}2 \\
4 \\
5\end{array}$ & $\begin{array}{l}29 \\
31 \\
29\end{array}$ \\
\hline $\begin{array}{l}\text { Carton, } \\
\text { jumble- } \\
\text { filled. }\end{array}$ & $\begin{array}{l}1 \\
2 \\
3\end{array}$ & $\begin{array}{l}42.1 \\
42.4 \\
42.9\end{array}$ & $\begin{array}{l}33 \\
25 \\
28\end{array}$ & $\begin{array}{r}65 \\
80 \\
113\end{array}$ & $\begin{array}{l}19 \\
34 \\
63\end{array}$ & $\begin{array}{r}2 \\
6 \\
12\end{array}$ & $\begin{array}{r}86 \\
120 \\
188\end{array}$ \\
\hline $\begin{array}{l}\text { Carton of } \\
12 \text { over-wrapped } \\
\text { trays. }\end{array}$ & $\begin{array}{l}2 \\
3\end{array}$ & $\begin{array}{l}32.4 \\
33.3\end{array}$ & $\begin{array}{l}0 \\
0\end{array}$ & $\begin{array}{l}33 \\
12\end{array}$ & $\begin{array}{l}28 \\
16\end{array}$ & $\begin{array}{l}2 \\
5\end{array}$ & $\begin{array}{l}63 \\
33\end{array}$ \\
\hline
\end{tabular}

12 replicates per test.

2 Fruit pressures (1b.) averaged 14.2 in test $1,11.8$ in test 2, and 10.5 in test 3. Firmness was measured by a Magness-Taylor pressure tester. 
There was considerably more damage in the other two packs (table 1). The polybagged fruit sustained an average of 24 punctures per 100 fruit without much variation in the three tests. Bruising damage, however, increased substantially with each test, pointing up the relationship between the firmness of the fruit and its susceptibility to bruising. This relationship was also evident in the jumble-packs, where the greatest amount of mechanical injury to fruit occurred. The number of bruises over $1 / 2 \mathrm{inch}$ soared from 86 per 100 fruit in the first run to 188 in the third run. The increases were of much greater proportions in the larger-size bruise categories. New punctures per 100 apples ranged from 25 to 33 in the three trips.

\section{RETAIL TESTS}

\section{Methods}

Three retail store tests were conducted in 1962 with the cooperation of a large food chain organization that regularly received its McIntosh apples in cartons of cell-packs and prepackaged poly-bagged units. For comparison studies, the inclusion of shrink-film overwraps was effected in some supermarkets in New York City. Two tests were made in January and one in March.

The apples selected for the January tests were U. S. Fancy grade fruit from Hudson Valley commercial cell packs of 120 fruit. The bruises and punctures, principally minor, were scored and averaged. The fruit was randomized and repackaged in 3-lb. poly bags ( 12 bags per carton), in shrink-film overwrapped trays ( 16 trays per carton), and in cell cartons of 120 apples.

In the March test, the test cartons of cell packs and of overwrapped trays were similarly made up from commercial cell packs of 120 (2 3/4" size) with McIntosh from a controlled atmosphere (CA) stored lot. For a more realistic comparison, the poly bags were prepackaged commercially with CA fruit from the same lot of a wider size range, having a $21 / 4$ inch minimum. The amount of mechanical injury present in this fruit when packaged was estimated by inspecting a representative number of bags, 24 out of the test lot of 288 , at the packinghouse.

A sufficient number of test packages was prepared to provide for a 1 - to 2-day supply for each store selected. The supply ranged from 3 to 5 cell cartons, 3 to 6 cartons of overwrapped trays, and 4 to 12 cartons of poly-bagged fruit. In January, the packages were delivered to one supermarket directly for testing. In March, the packages were delivered to the chain's warehouse; from there they were distributed by commercial trucks to two supermarkets. The fruit was refrigerated in the stores until displayed for sale. Apples from the cell packs were displayed in bulk on the fruit counter, as was customary, while the prepackaged units were displayed separately in layers of 3 to 4 tiers. To measure quality deterioration on the retail counter, apples were sampled every 2 hours during a 1 - to 2 -day retail period.

\section{Results and Discussion}

The results of the January tests are summarized in table 2. They indicate the deterioration that took place in the store. In both tests, the only change in quality noted during the short retail period was that brought on by mechanical injury, caused for the most part by shoppers. The increase in bruises over $1 / 2$ inch in size and in punctures was very low in the overwrapped trays. The attractive appearance of this consumer unit reduced handling by shoppers and helped to maintain sales at a fairly good pace.

While mechanical injury was greatest in the poly-bagged fruit, it wasn't excessive. The uniform size and the good appearance of the U. S. Fancy grade fruit within the poly bags plus a good price differential spurred sales of this item substantially. 
TABLE 2.-Net increases ${ }^{1}$ of punctures and bruises retailed in McIntosh apple samples

\begin{tabular}{|c|c|c|c|c|c|c|c|c|}
\hline \multirow{2}{*}{$\begin{array}{c}\text { Method } \\
\text { of } \\
\text { merchandising }\end{array}$} & \multirow{2}{*}{$\begin{array}{l}\text { Month } \\
\text { tes.ted } \\
\frac{2}{2}\end{array}$} & \multirow{2}{*}{$\begin{array}{l}\text { Number } \\
\text { of } \\
\text { samples }\end{array}$} & \multirow{2}{*}{$\begin{array}{l}\text { Number } \\
\text { of } \\
\text { apples }\end{array}$} & \multirow{2}{*}{$\begin{array}{l}\text { Punctures } \\
\text { per } \\
100 \text { fruit }\end{array}$} & \multicolumn{4}{|c|}{$\begin{array}{c}\text { Size and number of bruises } \\
\text { per } 100 \text { fruit }\end{array}$} \\
\hline & & & & & $1 / 2^{\prime \prime}-3 / 4^{\prime \prime}$ & $3 / 4 "-1 "$ & Over I" & Total \\
\hline & & & & & No. & No. & No. & No. \\
\hline $\begin{array}{l}3-1 b \cdot \text { poly } \\
\text { bags }\end{array}$ & $\begin{array}{l}\text { Jan. } \\
\text { March }\end{array}$ & $\begin{array}{l}18 \\
23\end{array}$ & $\begin{array}{l}175 \\
273\end{array}$ & $\begin{array}{l}76 \\
61\end{array}$ & $\begin{array}{r}59 \\
103\end{array}$ & $\frac{13}{25}$ & $\frac{1}{3}$ & $\begin{array}{r}73 \\
131\end{array}$ \\
\hline $\begin{array}{l}\text { Bulk (from } \\
\text { cell cartons) }\end{array}$ & $\begin{array}{l}\text { Jan. } \\
\text { March }\end{array}$ & $\begin{array}{l}17 \\
21\end{array}$ & $\begin{array}{l}136 \\
168\end{array}$ & $\begin{array}{l}58 \\
32\end{array}$ & $\begin{array}{l}46 \\
89\end{array}$ & $\begin{array}{l}6 \\
9\end{array}$ & $\frac{1}{2}$ & $\begin{array}{r}53 \\
100\end{array}$ \\
\hline $\begin{array}{l}\text { Overwrapped } \\
\text { trays. }\end{array}$ & $\begin{array}{l}\text { Jan. } \\
\text { March }\end{array}$ & $\begin{array}{l}17 \\
23\end{array}$ & $\begin{array}{l}136 \\
184\end{array}$ & $\begin{array}{l}1 \\
1\end{array}$ & $\begin{array}{r}4 \\
51\end{array}$ & $\begin{array}{r}1 \\
28\end{array}$ & $\begin{array}{l}0 \\
1\end{array}$ & $\begin{array}{r}5 \\
80\end{array}$ \\
\hline
\end{tabular}

1 After fruit was delivered to store by USDA personnel in January tests. After fruit was delivered to distributing warehouse by USDA personnel in March test.

2 Fruit pressures in 2 Jamuary tests averaged 10.6 and 11.1 lb. Fruit pressures in March test averaged $10.7 \mathrm{Ib}$.

Movement of the fruit from cell packs was good also. However, the samples from the bulk displays indicated that almost as much deterioration had taken place in this fruit as had occurred in the poly bags.

In the March test bruising was much more pronounced in all samples, which were collected over a 2 -day period in 2 stores (table 2). Fruit firmness wasn't much of a factor since flesh firmness of the March apples averaged within $1 / 2$ pound of that in the January tests. The crinkled condition of some of the cartons upon reaching the store indicated rough handling of these apples from the warehouse to the two stores, both of which were located less than 2 miles away. Undoubtedly, this accounted for some of the increase in bruising damage.

While the increase in bruising in the March test was high in all the samples, the manyfold increase in the shrink-film overwraps over the bruising found in the January tests was particularly striking. Bruises over $1 / 2$ inch totaled 80 in contrast to the 5 found per $100 \mathrm{fruit}$ in the earlier tests. From the location of the bruises and the condition of the tray partitions, much of the damage could be attributed to the failure of the partitions to withstand the damaging overhead stresses that were occasioned by rough handling of the cartons. The commercial 125-pound test fiberboard partition was simply not strong enough to protect the fruit in this relatively expensive pack. In the last transit test, the replacement of the commercial tray partition with a more rigid one, made from layer pad material, had greatly increased the protection of the fruit in this pack (table 1 ).

Despite the large increase in bruising damage in the overwrapped trays, the overall condition was still superior to that of the others. There was only 1 new puncture per 100 of these fruit sampled. As before, the condition of the poly-bagged fruit had deteriorated the most, while that of the bulk fruit was intermediate between the two prepackaged units.

The March samples were held under conditions favoring decay to determine whether any differences that resulted could be related to the way the samples were merchandised. After being held 4 days at $70^{\circ} \mathrm{F}$. and 85 to 90 percent relative humidity, 18. 6 percent of all the sampled fruit decayed (table 3). Many of the rot lesions were under $1 / 2 \mathrm{inch}$ in diameter. In all but 2 of the 116 fruit affected, decay developed in puncture sites which were made, usually by stems, in fruit en route to and while in the stores. The immobilization of the apples in trays by the shrink-film overwrap reduced puncturing to a minimum, and less than 1 percent of the apples in these trays decayed. Punctures were much 
TABLE 3.-Decay development in retail store samples of apples held 4 days at $70^{\circ} \mathrm{F}$. after retail

\begin{tabular}{|c|c|c|c|c|c|c|}
\hline \multirow[t]{2}{*}{ Sample } & \multirow{2}{*}{$\begin{array}{l}\text { Number } \\
\text { of } \\
\text { samples }\end{array}$} & \multirow{2}{*}{$\begin{array}{c}\text { Number } \\
\text { of } \\
\text { apples }\end{array}$} & \multicolumn{4}{|c|}{$\begin{array}{c}\text { Surface lesion size and percent } \\
\text { of fruit decayed }\end{array}$} \\
\hline & & & Less $\operatorname{than} 1 / 2 "$ & $1 / 2^{\prime \prime}-1 "$ & Over I" & Total \\
\hline & & & Pct. & Pct. & Pct. & Pet. \\
\hline 3-lb. poly bag..... & 23 & 273 & 14.3 & 11.4 & 2.9 & 28.6 \\
\hline 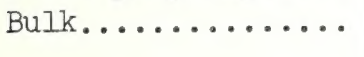 & 21 & 168 & 14.3 & 7.1 & .6 & 22.0 \\
\hline Overwrapped tray... & 23 & 184 & .5 & 0 & 0 & .5 \\
\hline
\end{tabular}

more numerous in the poly-bagged and bulk fruit samples (table 2), however, and much more decay resulted (table 3). Most of the decay was caused by the common blue mold fungus, Penicillium expansum.

\section{LITERATURE CITED}

(1) Burt, Stanley W.

1959. An Experimental Packing Line for McIntosh Apples. An Interim Report. U.S. Dept. Agr. AMS-330, 28 pp., illus.

(2) Ceponis, M. J. , Kaufman, J., and Ringel, S. M.

1962. Quality of Prepackaged McIntosh Apples in New York City Retail Stores. U.S. Dept. Agr. AMS-461, 12 pp.

(3) Evans, H. C., and Marsh, R. S.

1958. Costs and Mechanical Injury in Handling and Packing Apples. W. Va. Agr. Expt. Sta. Bul. 416,26 pp.

(4) Fountain, James B.

1962. Prepackaging Medium-size Apples in Shrinkable Films at Shipping Point.

U.S. Dept. Agr. Mktg. Res. Rpt. 534, 28 pp., illus.

(5) Perkins, F.A.

1961. Handling Apples From Storage to Customer. (N. J.) Hort. News 42: $25,32$.

(6) Perkins, F. A., and Underwood, J. W.

1960. Improved Consumer Packages for Maine McIntosh Apples. Maine Agr.

Expt. Sta. Bul. 591, 21 pp.

(7) Roberts, O. C.

1959. Causes and Effects of Mechanical Injuries to McIntosh Apples. Mass. Agr. Expt. Sta. Bul. 520, 39 pp.

(8) Schomer, H. A.

1957. Bruising of Apples: Where Does It Occur and How Can It Be Minimized?

Wash. State Hort. Assoc. Proc. 53: 129-131.

(9) Shadburne, Ronald A.

1959. Loading Methods for Truck Shipments of Apples in Fiberboard Boxes. An

Interim Report. U.S. Dept. Agr. AMS-321, 27 pp., illus. 

